\title{
When the earth moves under your feet
} Images of overcoming persecution in the Book of Psalms

\author{
Søren Holst
}

Aвstract - This article explores the overcoming of evil in the biblical Book of Psalms, taking as its point of departure the so-called 'sudden change of mood' in the individual psalms of lamentation, where a psalmist proceeds from complaint to grateful praise with no obvious explanation. Previous and more recent attempts at explanation are introduced, one of them the work of Jakob Wöhrle, pointing out that lament and praise correspond to two separate aspects of God, as 'hidden' and 'saving' respectively. It is suggested that these aspects should not be seen as equally fundamental: applying insights from Jon D. Levenson and Hans J. Lundager Jensen, it is argued that the psalmist's transition from despair to contentment reflects the assumption that evil is an external threat to the created order, not an aspect of the creator himself. This is further illustrated by the metaphorical use of the word mot, 'to stagger', in the Book of Psalms.

The Book of Psalms in the Hebrew Bible is rich in images of persecution, and almost equally rich in images of a life free of persecution, but is rather sparse in describing the transition from one to the other. In many psalms, the transition is not described at all, but taken for granted. This has seemed baffling, both to historically oriented scholarship and other reading strategies. In what follows, I first describe previous contributions that try to explain this, then attempt to throw light on the phenomenon from a more general consideration of the origin of evil and suffering according to the Hebrew Bible, and lastly illustrate this connection by surveying the use of a widespread metaphor in the Book of Psalms.

\section{From lament to praise}

The Book of Psalms in Hebrew bears the title Tehillim, meaning praises. But if one attempts to divide up the 150 songs by category, as the most important school in historical biblical scholarship in the twentieth century eagerly attempted, it soon emerges that the most frequent sort of psalm is the individual lament, that is, a song in which an individual Israelite describes to God his (or her?) specific plight and asks for help from the trouble that he is in. More of the psalms belong to this category than to any other (Kraus i978: 39).

As a matter of fact, it has been frequently noticed ever since scholars began focusing on categories of genre within the Psalms that a single psalm often contains the most sincere and indeed desperate plea for help together with expressions of trust that God is not just able but also willing to help. The psalm often goes to the rhetorical extreme of claiming that help from God has already been received, and - the most baffling aspect, in the eyes of scholars lamentation often occurs directly side by side with trustful declaration that divine help has taken place, the transition sometimes taking place within a single verse or indeed a single sentence, so that scholars have found it necessary to invent a specific term for this rhetorical 
and psychological phenomenon, referring to it as a characteristic Stimmungsumschwung. In the less expressive idiom of Anglophone literature, this is often rendered a 'sudden change of mood', but an Umschwung is of course literally an actual reversal or an 'about-face'.

The juxtaposition of lamentation and a more hopeful and trusting tone is not only found in the psalms that have an actual Umschwung; it is quite ubiquitous.

An example is Psalm 94: in the very first verses, the psalmist is alarmed by the fact that, although he refers to God as 'the God of retribution' (one might also translate el-nqamot more bluntly as 'God who carries out acts of revenge'), God apparently displays no inclination whatsoever to hold evildoers accountable for their deeds: 1

God of retribution, Lord,

God of retribution, appear!

Rise up, judge of the earth,

give the arrogant their deserts!

How long shall the wicked, O Lord,

how long shall the wicked exult, shall they utter insolent speech, shall all evildoers vaunt themselves? (Ps. 94:I-4)

That persecution is no exaggerated description of the activity of these evildoers is obvious:

They crush Your people, O Lord, they afflict Your very own;

they kill the widow and the stranger;

they murder the fatherless,

thinking, 'The Lord does not see it, the God of Jacob does not pay heed.' (vv. 5-7)

1 Unless otherwise noted, Bible quotations are taken from the JPS translation available at $<$ http://www.taggedtanakh.org >.
And the psalmist expresses his understandable frustration in the rhetorical question

Who will take my part against evil men?

Who will stand up for me against wrongdoers? (v. I6)

The answer, evidently, ought to be 'The Lord!', but at least in part of the psalm, this is not borne out by the psalmist's real-life experience.

This raises the question of what sort of coping strategy (or what sort of experienced external intervention) it is that enables the psalmist to claim a few verses later (v. 22), that 'the Lord is my haven; my God is my sheltering rock'.

The standard answer for much of the twentieth century has been based on the assumption that we need to understand each genre within the Psalter against the background of the specific sort of situation in which it was put to actual use: its Sitz-im-Leben, in the mother tongue of twentieth-century Bible studies. This refers, not to a unique historical situation specific to one particular person, but rather to the typical situation in which the Psalm would recurrently have had its function. In the case of an individual lament it would be the case of a person persecuted or subject to unjustified accusations who turns to the temple for help, support and, above all, justice. Against this background, the psalmist's sudden change of mood would then be explained by the fact that the psalm records only the words to be spoken by the one seeking protection. In between the complaint and the expression of trust, however, words would have been spoken by a priest at the temple in the form of an oracle conveying a divine message of justification and help (Küchler i9 18: 299-300; Gunkel I933: 243-7).

The difficulty of this ingenious explanation, evidently, is the fact that in the text itself, the priestly oracle is simply not there! It is tempting to add that an interpretation based on what may have happened when the Psalm was used, rather 
than on what the Psalm itself says, seems more of a hindrance than a help in the hermeneutical task of considering whether the text may contribute anything of relevance to a discussion of dealing with inhumanity in a present-day context.

Scholars in favour of this interpretation, however, have suggested that we actually do find examples of such priestly oracles of salvation, they are just not written down in the lament Psalms themselves (the psalms being, as we noted above, seen as a record of what supplicants and not the cultic professionals were to utter). Oracular utterances guaranteeing divine help to a human counterpart in need are nonetheless found, namely in the prophets, in contexts demonstrably influenced by the language of the Psalms (Begrich I 934: 8 I-2).

In the latter half of the Book of Isaiah, we frequently find comforting and cheering divine utterances such as the following:

For I the Lord am your God,

Who grasped your right hand,

Who say to you: Have no fear;

I will be your help.

Fear not, ... - declares the Lord -

(Isa. 4I:I3-I 4)

This, according to this school of thought, would actually be an example of a priestly oracle to those seeking help at the temple - or at the very least an example of the prophetic literature taking up the genre of the priestly oracle and using it within the context of prophetic instruction to Israel. The close correspondence, both in language and content, between the psalms of lamentation and the prophetic oracle make this likely (Begrich I 934: 82-91).

It is a nice idea. And indeed one could construct a neat-looking psalm by inserting the passage from Isaiah into the Psalm text where the 'sudden change of mood' takes place. But it remains an utterly speculative solution. Uwe Rechberger has thoroughly and convincingly criticised the claim that these passages in Isaiah are oracles in the sense claimed by Joachim Begrich (Rechberger 2012: 55-95). Furthermore, Dorothea Erbele-Küster has pointed to the insight of contemporary literary theory that texts are supposed to have Leerstellen (spaces left empty, following the terminology of Wolfgang Iser). The filling in of such spaces is part and parcel of the practice of reading, and we should be wary of assuming that something is left out by mistake and must be reconstructed (Erbele-Küster 2003: 498-9; cf. 2013: I6I-7). Therefore, a number of scholars, principally German, have attempted over the last few decades to deal with the issue based on what the text actually says.

\section{A paradigm of trust}

Christoph Markschies and Bernd Janowski have suggested that the combination of lament and trust display 'a paradigm of trust directed to its objective' (ein zielgerichtetes Vertrauensparadigma, Markschies I99I), in which the experienced absence of God in the lamentation parts of a psalm and the hoped-for presence of God in the part expressing trust go hand in hand. The seeming contradiction is to be resolved by realising that the act of lamenting is in itself an expression of trust, and the entire prayer reflects a coherent process in which the psalmist, by appealing to God, works his way towards a new view of his situation (Janowski 2009: 75-84). Beat Weber, in a similar vein, stresses that a continuity, as well as a contrast, exists between the lament and the thanksgiving (2005: I 26-7). The two constitute a dialectic of 'not yet' over against 'already' (ibid. I $32-3$ ). This unity between relating to the divine in praise and lament is further underscored when it is pointed out, that within an individual Psalm, the movement is not necessarily from lament to praise, but may go in the opposite direction (Villanueva 2008: $20 \mathrm{I}-3 \mathrm{I}$ ) or a dialectic between the two may find 
literary expression in a number of other ways. This emphasises the theological importance of lament as a legitimate way of addressing God, and not just as a transitory phase leading towards praise (ibid. 249-56). Similarly, LeAnn Snow Flesher has demonstrated that the praise, no less than the explicit lament, may be seen as a rhetorical device intended to move the heart of God concerning the psalmist's plight (Flesher 2008: $38-45$ ).

This body of scholarly work in itself constitutes a major improvement in the reading of these texts. Two contributions could fruitfully supplement it, I think. One is explicitly an attempt to correct especially Janowski's and Markschies's position. Another has - to the best of my knowledge - not previously been taken up in this context.

\section{Different dimensions of the divine}

The idea that lament in itself is an expression of trust is disputed by Jakob Wöhrle, who attempts to show in analysis of individual examples of the genre, that the idea does not do justice to the text. In his eyes, what is missing in order to achieve an adequate reading of the laments is an awareness that the two modes of approaching the divine in lamentation and trust correspond to fundamentally different conceptions of the divine. Janowski's and Markschies's claim of coherence thus glosses over a tension that is actually to be taken seriously. In the lament, God is seen as responsible for the suffering of the psalmist - if not in actually sending it, then in 'hiding his face', as the ubiquitous phrase in the Palms has it. By contrast, in the utterance of trust, God is addressed as the one who has actually shown - or is expected to show - a totally different aspect of himself in turning back to the psalmist (Wöhrle 20 I I: 235-6).

Wöhrle starkly demonstrates this duality by the simple expedient of pointing out how, on the one hand, these laments are extremely close in structure to a specific category of older Mesopotamian laments, the $\check{s} \mathcal{u}$-ila incantations, while, on the other hand, they differ in one fundamental respect.

Like the biblical individual lament, the $\check{s} u$-ila contains an introductory invocation of the deity, a presentation of the supplicant's plight, and a passage of thanksgiving, trust and praise (Zgoll 2003: 33-7). The supplicant's problem typically consists in having been estranged from, or attacked or abandoned by, his personal god or goddess. In this situation, the supplicant turns to a named high god, petitioning him or her to intervene (Lenzi 20 I O: 3 I I). In other words, the one simple, but highly significant, difference between the Mesopotamian and biblical lament is that in the $r u$-ila incantations, one deity is blamed for having abandoned the supplicant, and as a result, appeal is made to another deity for help. In the context of the Hebrew Bible, evidently, one God will have to fill both functions, and therefore it is not surprising, if the form of such laments goes back to a polytheistic context, that a tension is felt between the two modes of addressing God (Wöhrle 20 I I: 2374I; cf. Lundager Jensen r 998: 74-8).

Wöhrle sees his thesis as an alternative to that of Markschies and Janowski, but it might perhaps better be considered as a clarification: Wöhrle fruitfully supplements the thesis of the Janowski school of thought by spelling out the full theological import of the tension between lamentation and trust. Markschies and Janowski, on the other hand, demonstrate how trust can be inherent in the lament, exactly because according to the Hebrew Bible, the God who has abandoned the psalmist is the same one to whom he looks for help.

\section{The persistence of evil in creation}

The work of Wöhrle himself, I furthermore suggest, may need to be nuanced in one regard. Wöhrle presupposes that the power responsible 
for the suffering of the psalmist must of necessity be the one God. But while it is certainly true that in the Hebrew Bible, God is the only independently active power of any significance beyond humanity itself, the Bible frequently deals with what we might call 'the passive resistance of evil' in creation. It is generally agreed, for example, that in certain passages of the Psalms celebrating God's power as evidenced in creation, God is described as not just willing the world into existence with his word, but as subduing in combat the powers that are in the way of creation. An example is Psalm 74:

O God, my king from of old, who brings deliverance throughout the land; it was You who drove back the sea with Your might,

who smashed the heads of the monsters in the waters;

it was You who crushed the heads of

Leviathan,

who left him as food for the denizens of the desert;

it was You who released springs and torrents, who made mighty rivers run dry; the day is Yours, the night also; it was You who set in place the orb of the sun; You fixed all the boundaries of the earth; summer and winter - You made them. of Noah's flood) chaos immediately returns as a result (Levenson I 994: I4-25).

This idea, then, seems to be widespread in the Hebrew Bible: evil is persistent in the world, not because a figure like the 'Satan' of later tradition is to be imagined, or because doubts about God's power to eventually subdue evil can seriously be entertained. Rather, for frustratingly mysterious reasons God seemingly chooses not yet to impose his will upon the world and thereby free it of evil. And as long as this is the case, the world - left to its own devices has an inherent tendency to disintegrate into chaos. Whenever God hides his face, as psalmists frequently express it, a small sample of this returned chaos is experienced.

This is obviously the case on what we might call the cosmic level, in creation stories such as the passage just referred to. The tendency, however, of the created world to return to chaos unless upheld by perpetual divine maintenance can be seen not only on the cosmic, but also on the national level of Israel, as well as on the individual level of the single pious Israelite, or simply the individual human being (Levenson I 994: 26-46). The pious man may in this connection be taken as also metaphorically representing any single human being, since the parts of the Hebrew Bible that deal with the individual take little or no interest in ethnicity: ${ }^{2}$

$$
\text { (Ps. 74:I 2-I 7) }
$$

The Jewish Bible scholar and theologian Jon Levenson has done important work on the theological implications of this idea. Many parts of the Hebrew Bible take for granted that God conquered and subdued evil in the form of the dragon Leviathan, but did not destroy it.

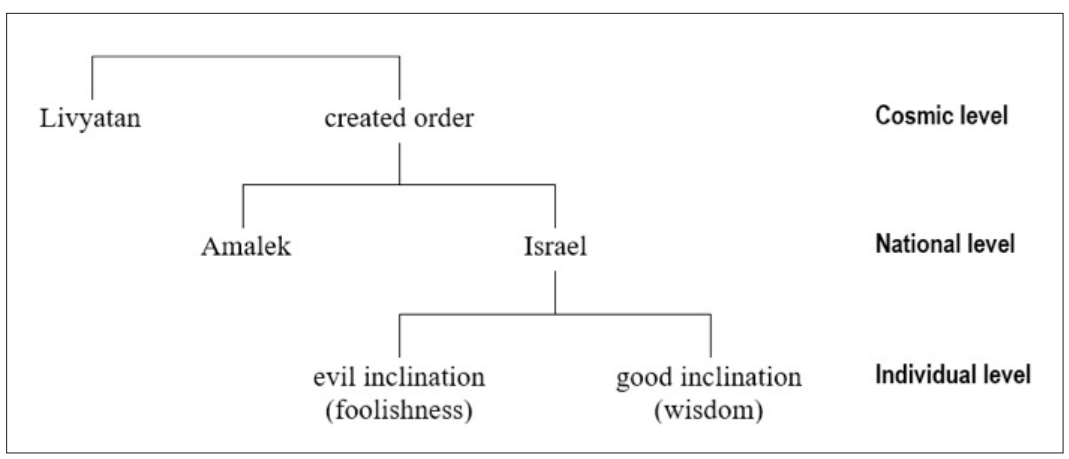

His continued creative action consists precisely in keeping it at bay, but whenever he desists from this work (as most prominently seen in the story

2 The illustration is inspired by Lundager Jensen (I 998: 97-108) who makes the same point as Levenson. 
The same danger which on the cosmic level is represented by Leviathan's threat of destruction to the created order exists on the national and individual level as well. In the Bible's telling of Israel's story, which focuses on the national level, the threat of destruction is represented by the other nations, sometimes summed up under the name Amalek (in the Bible an individual nation), which in rabbinic literature takes on a symbolic force as gentile persecution incarnate, which makes it an even more obvious parallel to Leviathan.

On the individual level, the Bible talks about wisdom and folly as powers vying for control of Man, whereas Rabbinic Judaism develops the distinction between the good and evil inclination present in every human being. On all levels something comparable to the entropy that physics talks about threatens the world that God initially deemed good.

\section{Staggering feet, toppling world}

The connection goes further than a merely structural similarity, however. This becomes clear if we investigate one of the specific images employed by a number of Psalms in dealing with persecution.

In Psalm 94, the psalmist answers his own rhetorical question as to who will take his part and stand up for him against evil men and wrongdoers, by describing the help he receives from God in the following way:

When I think my foot has given way,

Your faithfulness, O Lord, supports me.

(Ps. 94:I 8)

One would think that to a psalmist who is being openly and violently persecuted, stepping securely as opposed to tottering slightly would be the least of worries. But evidently the question of not faltering in your steps is a metaphor of fundamental importance in the Psalms. The vast majority of the uses of this specific Hebrew verb for staggering, mot, come from the book of Psalms. Although variously translated as 'totter', 'give way', 'be shaken' or 'topple', the same verbal root occurs 26 times in 2 I different psalms. ${ }^{3}$ It occurs regularly as a description of misfortunes actually met with or imminently threatening the psalmist, and constitutes the opposite of being secure (cf. Weber 2005: I 27-8):

Look at me, answer me, O Lord, my God!

Restore the luster to my eyes,

lest I sleep the sleep of death;

lest my enemy say, 'I have overcome him,' my foes exult when I totter. (Ps. I 3:4-5)

It is equally present in the so-called Psalms of trust, spelling out what the psalmist no longer needs to fear:
My help comes from the Lord, maker of heaven and earth.
He will not let your foot give way; your guardian will not slumber; See, the guardian of Israel neither slumbers nor sleeps! (Ps. I 2 I:2-4)

Moreover, in the characteristic style of biblical Hebrew poetry, verbal images are enriched with metaphorical content by the very fundamental literary trait of the parallelism that aligns two expressions and implicitly claims for them either actual identity of content or some sort of direct relation: in Psalm 94, the lines

3 In addition to the passages explicitly quoted, staggering describes the troubles of the afflicted individual in 38:17. Its absence occurs as a description of the safe situation of the trusting psalmist in $\mathrm{I} 6: 8 ; 17: 5 ; 62: 3,7$ and 30:7-8 (in explicit contrast to the experience of God hiding his face). The wicked mistakenly boasts of not staggering in Io:6. Finally, freedom from staggering describes the rewards of wise and pious living in general in I $5: 5$ and I $2: 6$. 
immediately following the description in verse I 8 of how the Lord supports the potentially staggering psalmist, broaden the scope of this support in the following way.

When I am filled with cares,

Your assurance soothes my soul. (v. I 9)

This could be more literally translated as 'When worries [or even more literally: "division"] multiply in my innards, Your consolation delights my nefesh [my "self"]'. It is problematic that the JPS translation renders nefesh by the 'literal', but potentially misleading, 'soul' - a concept mostly foreign to the Hebrew Bible - but obscures, through a less literal translation, how the worries haunting the psalmist are perceived as being physically located in his 'inward parts'.

Cares and doubts ravaging the psalmist's whole person and experienced as physical pain in his abdomen are thus set before the reader as the closely connected counterpart to the visible phenomenon that his feet may refuse to carry him. He is, to speak more modernly, going to pieces both physically and mentally.

Even more dramatically, the passage from Psalm I3 explicitly associates the faltering step of the Psalmist to death itself:

... lest I sleep the sleep of death;

lest my enemy say, 'I have overcome

him,'

my foes exult when I totter.

(Ps. I3:4-5)

Here, in other words, the staggering steps are those of a dying man. To live is to walk safely on one's feet. And conversely, to walk without staggering or faltering is identical to being 'in the land of the living', as other Psalms put it, for example when they equate suffering and persecution to being pent up with no room to move, and describe the end of their troubles as walking out into the open land (cf. Holst 20I4: 266-70, 274-9).

Having caught sight of this association of ideas, we re-encounter it if we look back to Psalm 94, since in the immediately preceding verse, it says

Were not the Lord my help,

I should soon dwell in silence. (Ps. 94: I 7)

Dwelling in silence - in dumab - means neither more nor less than being in one's grave, or in Sheol, the realm of the dead, which amounts to the same thing (cf. Ps. I I $5:$ I 7 ).

If we apply the insights of conceptual metaphor theory and conceptual integration networks, or 'blending theory' (Holst 2014: 270-3), we can describe what happens in the Psalm as a blending of two conceptual input domains. The instinctive everyday experience that being whole and well, and indeed alive, equals 'being on your feet', is made to embody the desired situation of being free from persecution and death in the concept of not staggering:

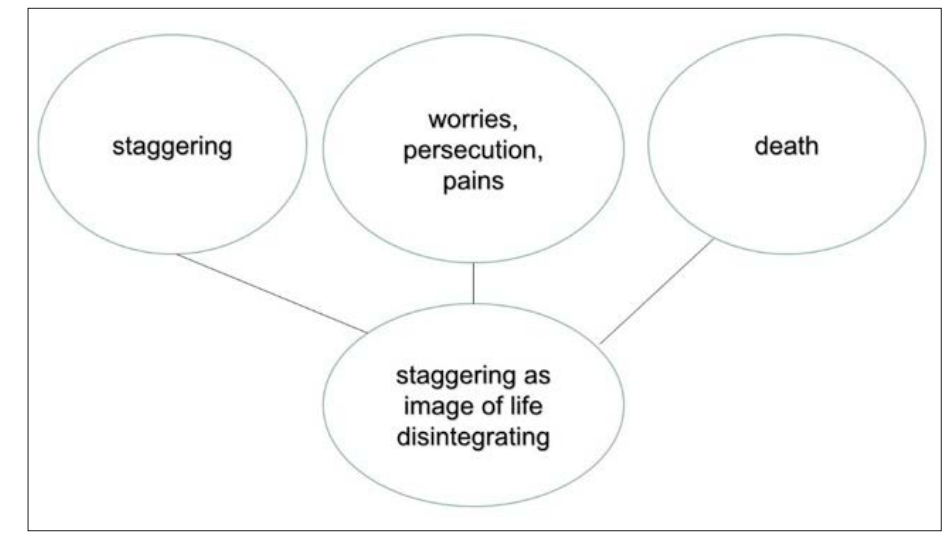

Now, why does walking firmly without fear of losing one's tread present itself to the psalmist as such an obvious metaphor when he wants to refer to life in its divinely intended, blessed form?

Light is thrown on this by an equally common use of the very same word that we translate 
'to stagger', when it concerns a person. We return here to the observation made above that the Hebrew Bible views the cosmic, the national and the individual levels of existence in structurally similar ways.

In several psalms and prophetic passages, it is not a human being, but the world itself that staggers, is in danger of staggering, or can be depended on not to stagger because God secures it - but only for that reason and none other:

The world stands firm; it cannot be shaken.

(Ps. 93:1, 96:10. I Chr. I6:30)

This is due, according to these Psalms, to the royal power of God: what he commands not to stagger, does not stagger. Elsewhere the same situation is associated with creation:

He established the earth on its foundations, so that it shall never totter. (Ps. I04:5)

Exactly as we saw in connection with the individual psalmist, however, this divinely guaranteed order is a precarious one, and by no means a matter of course. What God has brought about in creation - or in securing the individual life of a single Israelite - continues to be the case, only if God actively goes on to make sure that it stays this way. It is the general viewpoint of the Hebrew Bible that in the long run, he can indeed be depended upon to do this, but this conviction is presented in perpetual tension to the individual cases of observing that it seems not always to be so. This goes for the cosmic level as well as the individual:

Judge the wretched and the orphan, vindicate the lowly and the poor, rescue the wretched and the needy; save them from the hand of the wicked.

They neither know nor understand, they go about in darkness;

all the foundations of the earth totter.

(Ps. 82:3-5)
In Psalm 82, which is in many ways a difficult text, the exact thing that we were told in Psalm ro4 can never happen for all eternity, is in fact the case: the foundations of the earth are tottering, which is to say the created order is falling apart (cf. also Ps. 6o:4). The very first and most fundamental divine act of bringing the world into existence is in imminent danger of being negated. And we notice that this upheaval is connected directly to a lack of justice at the level of the persecuted individual.

Moreover, to fill out the picture: the middle level, the national one, may also be described using this specific cluster of metaphorical language. In Psalm 46 we start out at the cosmic level, the tone confident although the situation is actually one of cosmic upheaval:

God is our refuge and stronghold, a help in trouble, very near.

Therefore we are not afraid though the earth reels, though mountains topple into the sea ... (Ps. 46:2-3)

The cosmic view, however, is immediately transposed to the national one in the following verses:

God is in its [the city's] midst, it will not be toppled;

by daybreak God will come to its aid.

Nations rage, kingdoms topple;

at the sound of His thunder the earth dissolves.

The Lord of hosts is with us; the God of Jacob is our haven. (vv. 6-8)

Here it is the national entity that is potentially threatened by staggering to its defeat and destruction (cf. Ps. 2r:8 and 66:9). It is noteworthy - cf. the three-level chart above - that the destructive power which may be Leviathan on the cosmic level or personal persecutors on 
the individual, is here represented by 'nations ... kingdoms'. But God not only ensures that this does not happen, his active intervention consists in letting exactly the destructive phenomenon of losing one's foothold befall the threatening nations.

\section{The created order}

Summing these last examples up again with the aid of conceptual metaphor theory, we see that the book of Psalms combines images of stability and the threats posed to it on all three levels of the created world into a comprehensive picture of evil as an unexplained dimension of the created order. experienced, order and chaos are never presented as being on the same level. God's failure to intervene is and remains mysterious and inexplicable, but it is always, implicitly or explicitly, presupposed that God's non-intervention must be temporary. This is so, even if it should last long enough for the individual psalmist to go to his grave without seeing the end of it, as seems to be the case in Psalm 88. Assuming otherwise would go against the grain of the more fundamental assumption that God's activity is visible in the fact that the earth itself, under circumstances that our experience describes to us as normal, actually does not stagger. Thus, in Levenson's words, 'the overwhelming tendency of biblical writers as they confront undeserved evil is not to explain it away but to call upon God to blast it away' (Levenson I 994: xvii). The seemingly unexplained 'change of mood' that many psalms convey would seem to reflect the idea that the God called upon to come to the rescue, is not just, as Jakob Wöhrle would have it, identical to the God who has caused the suffering of the psalmist by hiding his face, but represents a more fundamental aspect of the divine.
The embodied conceptualization of stability and well-being in the life of the individual as 'not-staggering' is combined with the theological proposition that the firmness of the earth (and indeed the stability and continued existence of the cosmos) is a given, and divinely willed, but nonetheless precarious, result of the fundamental divine activity of creation.

The presence of persecution is perceived as the absence of the divinely created order (or indeed the absence of God), but it is maintained, at the same time, that this absence is an aberration, not a normal or reasonably expected phenomenon. Although the created order is precarious and its absence indeed frequently

\section{Conclusion}

Many psalms express an individual's distress at persecution and suffering and at the same time contain trust, hope and thanksgiving. We have gone over a number of explanations for this, from earlier attempts at seeking the explanation outside the text, in its situation of liturgical use, to present-day interpretations demonstrating that lament and praise stand in a meaningful, dialectic relation to each other in the text as it lies before us. The focus of Jakob Wöhrle on lamentation and praise as reactions to different aspects of the divine is especially interesting. These two expressions of the divine as 'hidden' and 'saving' were represented in Mesopotamian 
incantations by different deities, but the same literary and functional structure remains in biblical laments, in which the one God fills both roles. Drawing on Jon D. Levenson and Hans J. Lundager Jensen - and taking the idea of 'staggering' in the Psalms as a pertinent illustration - we noticed, however, that the two are not presented as being equally fundamental, as persecution and suffering are seen as temporary aberrations from the divinely willed order governing the world.

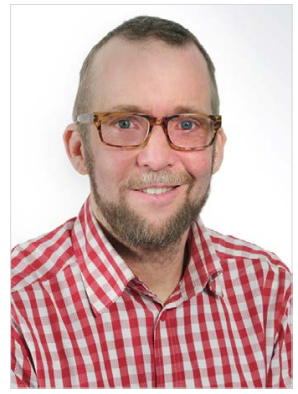

Søren Holst, PhD, is Associate Professor at the University of Copenhagen. He worked as assistant on the publication of the Dead Sea Scrolls in Jerusalem 1997-9. His dissertation, Verbs and War Scroll: Studies in the Hebrew Verbal System and the Qumran War Scroll, was published by Uppsala University Press in 2008. He has published in Danish on Genesis, Psalms and the Dead Sea Scrolls. He is currently engaged in re-editing manuscripts from Qumran Caves 4 and 1.

\section{References}

Begrich, Joachim, I 934. 'Das priesterliche Heilsorakel', Zeitschrift für die alttestamentliche Wissenschaft, 5 2, pp. 8 I -92

Erbele-Küster, Dorothea, 2003. 'Le Psaume 57 comme prière: l'apport de l'esthétique de la réception à l'exégèse biblique', Revue des sciences religieuses, 77, pp. 497-5 I I

-2013. Lesen als Akt des Betens. Eine Rezeptionsästhetik der Psalmen (Eugene, OR, Wipf \& Stock)

Flesher, LeAnn Snow, 2008. 'Rapid change of mood: oracles of salvation, certainty of a hearing, or rhetorical play?, "My Words are Lovely": Studies in the Rhetoric of the Psalms, eds. Robert L. Foster and David M. Howard, Jr. (London, T\&T Clark), pp. 33-45

Gunkel, Hermann, 1933. Einleitung in die Psalmen. Die Gattungen der religiösen Lyrik Israels (Göttingen, Vandenhoeck \& Ruprecht)

Holst, Søren, 20I 4. 'Psalmists in cramped and open spaces: a cognitive perspective on the theology of Psalms', Scandinavian Journal of the Old Testament, 28, pp. 266-79
Janowski, Bernd, 2009. Konfliktgespräche mit Gott. Eine Anthropologie der Psalmen (NeukirchenVluyn, Neukirchener Verlag)

Kraus, Hans-Joachim, I 978. Psalmen 1-59, Biblischer Kommentar zum Alten Testament I 5: I Neukirchen-Vluyn, Neukirchener Verlag)

Küchler, Friedrich, I 9 I 8. 'Das priesterliche Orakel in Israel und Juda', Abhandlungen zur semitischen Religionskunde und Sprachwissenschaft. Wolf Wilhelm Grafen von Baudissin zum 26. September 1917, eds. Wilhelm Frankenberg and Friedrich Küchler, Beihefte zur Zeitschrift für die alttestamentliche Wissenschaft, 33 (Giessen, Alfred Töpelmann), pp. 285-30 I

Lenzi, Alan, 201 o. 'Invoking the God: interpreting invocations in Mesopotamian prayers and biblical laments of the individual', Journal of Biblical Literature, I 29, pp. 303-I 5

Levenson, Jon D., I 994. Creation and the Persistence of Evil: The Jewish Drama of Divine Omnipotence (Princeton University Press)

Lundager Jensen, Hans J., 1998. Gammeltestamentlig religion (Copenhagen, Anis)

Markschies, Christoph, I99r. 'Ich aber vertraue auf dich, Herr!“ Vertrauensäußerungen als Grundmotiv in den Klageliedern des sEinzelnen', Zeitschrift für die alttestamentliche Wissenschaft, Iо3, pp. 386-98

Rechberger, Uwe, 20 I 2. Von der Klage zum Lob. Studien zum "Stimmungsumschwung" in den Psalmen, Wissenschaftliche Monographien zum Alten und Neuen Testament, I 33 (Neukirchen-Vluyn, Neukirchener Verlag)

Villanueva, Federico G., 2008. The 'Uncertainty of a Hearing': A Study of the Sudden Change of Mood in the Psalms of Lament, Supplements to Vetus Testamentum, I 2 I (Leiden, Brill)

Weber, Beat, 2005. 'Zum sogenannten "Stimmungsumschwung" in Psalm I3', The Book of Psalms: Composition and Reception, eds. Peter W. Flint and Patrick D. Miller, Supplements to Vetus Testamentum, 99 (Leiden, Brill), pp. I I 6-38

Wöhrle, Jakob, 20 I I. 'Der verborgene und der rettende Gott. Exegetische und religionsgeschichtliche Überlegungen zur Theologie der Klagepsalmen', Biblische Zeitschrift, 55, pp. 224-4s

Zgoll, Annette, 2003. 'Für Sinne, Geist und Seele. Vom konkreten Ablauf mesopotamischer Rituale zu einer generelle Systematik von 
Ritualfunktionen', Ritual und Poesie. Formen und Orte religiöser Dichtung im alten Orient, im Judentum und im Christentum, ed. Erich Zenger, Herders Biblische Studien, 36 (Freiburg, Herder), pp. 25-46 